\title{
Multiple Recruitment Limitation Causes Arrested Succession in Mediterranean Cork Oak Systems
}

\author{
Vanda Acácio, ${ }^{1,2, *}$ Milena Holmgren, ${ }^{3}$ Patrick A. Jansen, ${ }^{4}$ and \\ Ondrej Schrotter ${ }^{5}$
}

\begin{abstract}
${ }^{1}$ Forest Ecology and Forest Management Group, Center for Ecosystem Studies, Wageningen University, P.O. Box 47Wageningen, 6700 AA, The Netherlands; ${ }^{2}$ Centro de Ecologia Aplicada Prof. Baeta Neves, Instituto Superior de Agronomia, Tapada da Ajuda, Lisboa, 1349-017, Portugal; ${ }^{3}$ Resource Ecology Group, Center for Ecosystem Studies, Wageningen University, P.O. Box 47Wageningen, 6700 AA, The Netherlands; ${ }^{4}$ Community and Conservation Ecology Group, University of Groningen, P.O. Box 14Haren, 9750 AA, The Netherlands; ${ }^{5}$ Česká Zemědělská Univerzita v Praze, Fakulta Lesnická a Environmentální, Kamýcká 1176, Praha, 165 21, Czech Republic
\end{abstract}

\begin{abstract}
Lack of tree regeneration and persistency of species-poor shrublands represent a growing problem across Mediterranean evergreen oak forests. What constrains forest regeneration is poorly understood, and restoration attempts have been largely unsuccessful. We assessed the contribution of four different mechanisms of tree recruitment limitation (that is, source, dispersal, germination, and establishment) in a cork oak (Quercus suber) system in southern Portugal. Using a combination of field studies and experiments, we quantified seed production, seed removal and dispersal, seed survival and germination, seedling establishment and survival, as well as cork oak natural regeneration for the three dominant vegetation types in this system (Cistus ladanifer shrubland, oak forest, and oak savanna). We found that all four forms of cork oak
\end{abstract}

recruitment limitation were significantly more severe in shrublands than in oak forests and savannas, so that oak seedling recruitment in shrubland was impeded in multiple ways. Our results explain why transitions from shrublands to oak savannas and forests are extremely difficult, and that the release from arrested succession in this system requires the simultaneous relief of multiple constraints on recruitment limitation in the early life history of oaks. These results have important implications for the restoration and conservation of Mediterranean oak systems.

Key words: alternative states; Cistus ladanifer; facilitation; forest regeneration; seed dispersal; seed predation; seedling establishment; shrub encroachment; Quercus suber.

\section{INTRODUCTION}

Succession has traditionally been conceived as a relatively linear process, but evidence from a variety of ecosystems indicates that persistent alternative

Received 31 March 2007; accepted 26 July 2007; published online 9 October 2007.

*Corresponding author; e-mail: vanda.acacio@wur.nl vegetation or ecosystem states may occur, particularly after disturbances (Friedel 1991; Laycock 1991; Scheffer and others 2001). In these cases, succession is strongly delayed or practically stopped in a condition called arrested succession (Putz and Canham 1992; Sarmiento 1997). Clearly, understanding the mechanisms responsible for arrested succession and their relative importance across ecosystems will not only contribute to ecological theory but will also be 
of key importance to the development of conservation and restoration strategies.

Mediterranean ecosystems have been the subject of a long tradition of ecological studies. More recently, the recognition of Mediterranean ecosystems as one of the Earth's biodiversity hotspots (Myers and others 2000; Olson and Dinerstein 2002) has boosted the search for a clear understanding of the mechanisms of natural regeneration and the role of arrested succession. Mediterranean ecosystems have a long history of alteration by human disturbances such as grazing, clearing, and fire (Aschmann 1973; Trabaud 1981; Conacher and Sala 1998). Regeneration of original vegetation types after disturbance seems to be halted under certain circumstances, and some successional stages become notoriously persistent (Fuentes and others 1984; Westoby and others 1989; Puigdefábregas and Mendizabal 1998; Holmgren 2002).

Evergreen oak forests used to be widespread in the Mediterranean Basin (Walter 1973; Pignatti 1978). Today, small remnants persist in a very patchy landscape. In the Iberian Peninsula, original evergreen oak forests have been transformed by human management into a mosaic landscape of forest patches, oak savannas, shrublands, and grasslands. In the absence of human management, the usual pathway of natural succession in oak savannas is through the gradual colonization of the understorey by different shrub species (pioneer Cistus shrubs, followed by other shrub communities like Arbutus and Erica), mixed with oak natural regeneration, which leads to forest recovery in the medium-term (Natividade 1950; Gonçalves 1991). Although some natural forest regeneration has indeed occurred in some areas after agricultural land was abandoned during the 1960s (Mazzoleni and others 2004), the transition from shrublands to oak savannas and forests is rare (Natividade 1950; Rivas-Martínez and others 1990; Gonçalves 1991; Montero and others 1994). Recent estimations for southern Portugal indicate that $60 \%$ of the shrubland patches remain as such after 45 years (19582002) and less than $10 \%$ progress to oak savannas or forests (Acacio and others, unpublished results). The switch to shrublands may occur from the combination of different types of disturbances (grazing, large clearing for agriculture, or fire) with dry conditions (either south facing slopes, or several dry years). Furthermore, several studies have reported a lack of tree regeneration across the Iberian Peninsula both in oak-dominated patches (Montero and others 1994; Campos and others 1998; Montero and others 2000; Pulido and Díaz 2005), and in shrubland patches (Pons and Pausas
2006; Pausas and others 2006). Tree recruitment limitation in Mediterranean oak systems has been attributed to a variety of causes, including (1) low seed input due to scarcity of viable seeds and poor seed dispersal (Pulido and Díaz 2005), (2) high levels of seed predation by wild and domestic animals (Herrera 1995; Pulido and Díaz 2002; Gómez and others 2003; Leiva and Fernández-Alés 2003); and (3) low seedling survival due to thermal and water stress (Borchert and others 1989; Pulido 1999; Retana and others 1999; Gómez-Aparicio and others 2004).

In this paper, we assess the contribution of four mechanisms of recruitment limitation (sensu Nathan and Muller-Landau 2000; Schupp and others 2002)-source limitation, dispersal limitation, germination limitation, and establishment limitation-to the persistence and dynamics of the three dominant vegetation types in the cork oak landscapes of southern Portugal: forests, oak savannas, and shrublands. We expect seedling recruitment to be more constrained by each form of recruitment limitation in shrubland than in the other two vegetation types. Specifically, we tested the following hypotheses: (1) source limitation (that is, low seed availability) is greater in shrublands than in savannas and forests, due to a lack of adult trees and lower seed production per tree; (2) dispersal limitation (that is, failure of viable seeds to disperse to potential recruitment sites) is greater in shrublands than in savannas and forests, due to a higher pre-dispersal seed predation by mice and weevils (below adult trees) and lower dispersal by mice and jays in shrublands; (3) germination limitation (that is, failure of viable seeds to survive and germinate) is greater in shrublands than in savannas and forests, due to higher post-dispersal seed predation in shrublands and lower rates of germination; (4) establishment limitation (that is, failure of germinating seeds to establish into seedlings and survive) is greater in shrublands than in savannas and forests, due to higher seedling water stress in shrublands as a result of lower soil water availability and higher temperatures (Diniz 1994). We also tested whether these four types of limitation differed between forests and oak savannas.

Identification of the mechanisms that limit cork oak recruitment and contribute to their decreasing resilience is of vital importance for the management and restoration strategies of Mediterranean cork oak forests, which are classified as a protected nature conservancy area of Europe (Habitats Directive 92/43/EEC), and represent high economical value from cork production. 


\section{MeTHODS}

\section{Study Area}

The study area was located in Serra do Caldeirão $\left(37^{\circ} 14^{\prime} \mathrm{N}, 7^{\circ} 56^{\prime} \mathrm{W} ; 11,000 \mathrm{ha}\right)$, a mountain ridge in the northeastern part of the Algarve province, southern Portugal. The climate is Mediterranean with most rainfall concentrated in the winter months (December to February) and only $2.5 \%$ of the rainfall falling in the summer (June to August). Mean annual precipitation is $900 \mathrm{~mm}$ and mean annual temperature is $16.6^{\circ} \mathrm{C}$ (45-year period: 1958-2002, Barranco do Velho station). Altitude ranges from 146 to $588 \mathrm{~m}$. Soils are homogeneous, consisting mainly of schist lithosols (soils with hard rock occurring at less than $10 \mathrm{~cm}$ depth, in this case schist rock) (National Center for Soil Survey and Land Planning).

The landscape is a mosaic of three vegetation types, where each patch-type represents a different stage in the natural succession: (1) cork oak forests, (2) cork oak savannas, and (3) Cistus ladanifer shrublands. Cork oak forests have a closed canopy with high tree density (over 200 trees ha ${ }^{-1}$ ) and a diverse shrub layer (for example, Arbutus unedo, Viburnum tinus, Erica arborea, Pistacia lentiscus, Rhamnus alaternus, Phillyrea latifolia, Calluna vulgaris, Smilax aspera). Cork oak savannas (human-made savannas, traditionally named montados in Portugal and dehesas in Spain) are open canopy patches with lower tree density (less than 200 trees ha ${ }^{-1}$ ) and an herbaceous layer, which have been exploited as agroforestry systems for cork extraction, grazing, and crop production. Cistus shrublands are patches dominated by C. ladanifer shrubs with some Ulex argenteus, Genista hirsuta and Lavandula stoechas, and scattered cork oak trees (less than 100 trees $\left.\mathrm{ha}^{-1}\right)$. They are pioneer heathland species which usually invade cleared understorey patches that were exposed to long-term intensive land use and that have low soil water and nutrient conditions (Gonçalves 1991; Diniz 1994; Latorre 1996; Blanco and others 1997; Seng and Deil 1999).

Cork oak (Quercus suber) is a mast-seeding evergreen tree that dominates the late successional stages of this system. Seed predation is mainly caused by insects such as Curculio elephas (Coleoptera: Curculionidae) and Cydia splendana (Lepidoptera: Tortricidae), and wood mouse (Apodemus sylvaticus). The main seed dispersers are wood mouse and European jay (Garrulus glandarius), which tend to differ in abundance among vegetation successional stages; rodents are more abundant in shrublands, as jays are in forests.
In December 2003, we randomly selected nine experimental sites in the study area, with three replicates for each vegetation type, namely three forests, three savannas, and three shrublands, which measured $2,500 \mathrm{~m}^{2}$ each. In December 2004, we selected seven additional sites (three forests, two savannas, and two shrublands) to compensate for sites that were destroyed by a forest fire and shrub clearing practices and to rebalance the experimental design. The total number of sites used was 16. All sites were located less than $8 \mathrm{~km}$ apart, on north-northwest exposures. Adult cork tree density in our sites was $280 \pm 14$ trees $\mathrm{ha}^{-1}$ in forests, $165 \pm 22$ trees $\mathrm{ha}^{-1}$ in savannas, and $86 \pm 17$ trees ha ${ }^{-1}$ in shrublands (average \pm SD). For all experiments we collected fresh acorns at the end of November-beginning of December (natural period of availability) from the ground below several trees scattered through the study area. At each of the experimental sites, we quantified for cork oak: (1) natural regeneration; (2) seed production; (3) seed removal and dispersal; and (4) seed germination and seedling survival.

\section{Natural Regeneration}

To quantify seedling recruitment in the three vegetation types, we counted the naturally established seedlings $(<50 \mathrm{~cm}$ tall $)$ in three $4.5 \times 1 \mathrm{~m}$ plots per each site, separated by a distance of $3 \mathrm{~m}$ between each other. Natural regeneration was assessed at six forest sites, five savanna sites, and five shrubland sites. We counted seedlings in 3 years (May 2004, February 2005 and March 2006). Natural regeneration at each moment in time was then averaged per site and per vegetation patch-type. Natural regeneration at all sites includes seedlings originated from seeds and root sprouts because both can establish as new trees. We used analysis of variance (ANOVA) to test for differences in natural regeneration (no. seedlings $/ 4.5 \mathrm{~m}^{2}$ ) among forests, savannas, and shrublands and the post-hoc Tukey's pairwise test to test for differences. Values were log-transformed before analyses to meet the normality assumption.

\section{Seed Production}

To test whether seed source limitation was greatest in shrublands (hypothesis 1), we compared seed densities among the three vegetation types. We quantified seed availability by counting the number of acorns on a ground area of $0.5 \mathrm{~m}^{2}$ below five randomly selected adult cork oak trees at each site, located more than $15 \mathrm{~m}$ apart from each other. We sampled four sites for each vegetation type 
(including sites selected in both 2003 and 2004) in December 2005.

To estimate the crown area of each selected tree, we measured maximum and minimum diameters of the crown (visually selected under the crown) and calculated the crown projection area (using the formula for an ellipse). Crown surface was then averaged per site. To estimate the crop size, we multiplied the average crown surface by the geometric mean of the number of acorns per site. We finally multiplied the crop size by the number of trees $\mathrm{ha}^{-1}$ for each site, and obtained the number of acorns ha ${ }^{-1}$.

We used ANOVA to test for differences in seed production among vegetation types and the posthoc Tukey's pairwise test to test for differences. Values were log-transformed before analyses to meet the normality assumption.

\section{Seed Removal and Dispersal}

To test whether dispersal limitation was greatest in shrublands (hypothesis 2), we compared rates of seed removal and dispersal by scatter-hoarding rodents among the three vegetation types. Seed removal was measured by following the fate of tagged acorns placed at the experimental sites. We randomly selected three trees at each of 12 sites (four of each vegetation type). Trees were more than $15 \mathrm{~m}$ apart. We released 25 tin-tagged acorns on a $1 \times 1 \mathrm{~m}$ area at the base of each tree at the end of December during the natural period of acorn availability. These seeds had a thin 8 -cm-long metal thread with a numbered metal tag in the end (following Li and Zhang 2003; Xiao and others 2006). To make sure that the tagging did not affect seed removal, we released 25 extra acorns (numbered with a wax pen) at two trees in each experimental site. We found no differences in acorn removal between tagged and untagged seeds. A total of 38 trees and 1,510 acorns were used (520 acorns at shrublands and savannas sites; 470 acorns at forests).

We recorded the number of seeds that remained at 3, 30, 60, and 90 days after placement. At each census, we searched a $20-\mathrm{m}$ radius circular area around each release tree for tags of acorns that had been removed. For each retrieved tag (with or without acorn attached to it), we recorded whether the acorn was buried or eaten, and we measured the distance to the release point. Non-retrieved acorns were recorded as missing and were not included in the seed fate analysis. We also recorded infestation by insects of acorns that were not removed, because this factor is likely to affect the attractiveness of acorns for rodents; insect-infested acorns have a lower nutritional value and are more perishable (Den Ouden and others 2005). All tagged-buried acorns that we retrieved were monitored for germination for 90 days.

We used survival analysis (Klein and Moeschberger 1997) to test for differences in seed removal with R 2.3.0 (R Development Core Team 2006). Seed removal time was calculated as the time between release of the seed at the experimental tree and the first census in which the seed was recorded missing. We used Cox proportional hazards models (Cox 1972) to test for differences in seed removal between vegetation types. The cluster option was used to obtain robust coefficient-variance estimates, accounting for dependence of seed fate within stations (trees). Thus, stations (trees), rather than seeds, were treated as replicates. Additionally, we used ANOVA to test for differences among vegetation types in the proportion of seeds ultimately removed and the post-hoc Tukey's pairwise test to test for differences. Proportions were arc$\sin$ (square root)-transformed before analysis to meet the normality assumption.

\section{Germination and Seedling Survival}

To test whether germination limitation (hypothesis 3) and establishment limitation (hypothesis 4) were greatest in shrublands, we compared rates of seed germination and seedling survival among the three vegetation types. We sowed 50 seeds in each of our 16 study plots (six plots located in forests, five in savannas, and five in shrublands). We sowed 10 acorns with $50 \mathrm{~cm}$ interspacing along five parallel transects $2 \mathrm{~m}$ apart. Planting was done twice, at the beginning of December in 2003 (first cohort) and 2004 (second cohort at new sites). Three plots of the first cohort were destroyed by fire, and three plots (two of the first cohort and one of the second) were destroyed by shrub clearing before the end of our experiment.

We monitored acorn germination and seedling survival once a month at all plots during 2 years for the first cohort (March 2004-March 2006) and 1 year for the second (March 2005-March 2006). A seedling was considered dead if it was missing or if it was dry and did not resprout during the next 4 months. To relate seedling performance to the light microenvironment, we recorded whether each emergent seedling was in each of these four conditions: full-sun, half shaded by a tree, completely shaded by a tree, or shaded by a shrub. Most seedlings were shaded by trees in forests and were in full-sun in savannas. In shrublands, most seed- 
lings were under the shade of Cistus shrubs, whereas shrub-shade in forests and savannas resulted from other shrub species.

We used survival analyses (see above) to test for differences in seed germination and seedling survival. Germination time was calculated as the time between sowing and germination (that is, aboveground appearance of the radicle). Seedling survival time was calculated as the time between germination and the natural death of the seedling. Seeds/seedlings that were not removed by animals or had not germinated/died at the end of the study (or at the time of plot destruction) were included as censored observations (observations with incomplete information). We used Cox proportional hazards models to test for differences in seed germination and seedling survival between vegetation types, taking into account differences in observation time among seeds and seedlings, and using the cluster option to obtain robust coefficient-variance estimates, accounting for dependence of seed and seedling fates within plots. Thus, plots (rather than seeds and seedlings) were treated as replicates. Additionally, we used one-way ANOVA to test for differences among vegetation types in the proportion of seeds ultimately germinating and the proportion of seedlings ultimately surviving. Proportions were $\arcsin$ (square root)-transformed before analyses to meet the normality assumption.

\section{Recruitment Cycle}

We used the data on the four mechanisms of recruitment limitation to calculate the proportion of seedlings from the total seed production that could successfully establish in each vegetation type, as in Wang and Smith (2002). From the total estimated seed production (seed rain) we subtracted the proportion of seeds eaten by mice before dispersal (pre-dispersal predation, which we define as the proportion of acorns eaten below the parent tree) and after dispersal (post-dispersal predation, based on the proportion of acorns removed and eaten). We then calculated the proportion of seeds that were able to germinate, multiplying estimated germination rates by the total number of nonpredated seeds. Some of the removed seeds were scatter-hoarded and buried by mice (secondary dispersal), and were able to germinate. This proportion was added to the germinating proportion. Finally, from the total estimated number of germinated seedlings, we subtracted the proportion of seedlings that died (using estimated rates for seedling survival for each vegetation type) to calculate the proportion of seedlings that was able to establish successfully after 2 years, in each vegetation type.

\section{RESUltS}

\section{Natural Regeneration}

Natural seedling recruitment (averaged for the 3 years) was more abundant in forests (3.6 seedlings $\mathrm{m}^{-2}$ ) than in savannas $\left(1.1\right.$ seedlings $\left.\mathrm{m}^{-2}\right)$, and very low in shrublands $\left(0.1\right.$ seedlings $\left.\mathrm{m}^{-2}\right)$. Differences among the three vegetation types were significant $\left(F_{2,26}=35.2, P<0.001\right.$, and Tukey test $)$.

\section{Seed Production}

Acorn crop size (that is, number of acorns per tree) was highest in savannas and lowest in shrublands (Figure 1A), but the difference among vegetation types was not significant (ANOVA: $F_{2,9}=1.01$, $P=0.4)$. On the other hand, acorn production per ha differed significantly among vegetation types (Figure 1B, ANOVA: $F_{2,9}=11.9, P=0.003$ ). The overall seed production per ha was markedly higher in forests because of the larger tree density. However, differences between forests and savannas were not significant (Tukey test, $P=0.54$ ). Shrublands had the lowest seed production per ha (Figure 1B), significantly different from the other two vegetation types (Tukey test, $P=0.003$ for forests, and $P=0.02$ for savannas), which agrees with hypothesis 1 (source limitation).

\section{Seed Removal and Dispersal}

Predispersal seed predation by mice was lowest in savannas $(2 \%)$ and similar between forests $(10 \%)$, and shrublands $(8 \%)$. Weevil-attack on intact acorns was higher in shrublands $(42 \%)$ than in savannas $(12 \%)$ and forests $(9 \%)$. Therefore, the overall proportion of pre-dispersal predation (both mice and weevils) was highest in shrublands.

Seed removal was faster in shrublands than in savannas and forests (Figure 2). The difference among vegetation types was significant, even when accounting for dependence of removal rates within trees (Robust Cox regression: $U_{2}=9.43$, $P=0.009$ ). The estimated removal rate was 3.9 to 4.5 times higher in shrublands than in savannas and forests, but not significantly different between forests and savannas. After 3 months, the proportion of intact seeds remaining was lower in shrublands $(17 \%)$ than in savannas $(53 \%)$ and forests $(64 \%)$ (Figure 2), but this difference was not significant (ANOVA: $F_{2,9}=3.2, P=0.09$ ). 

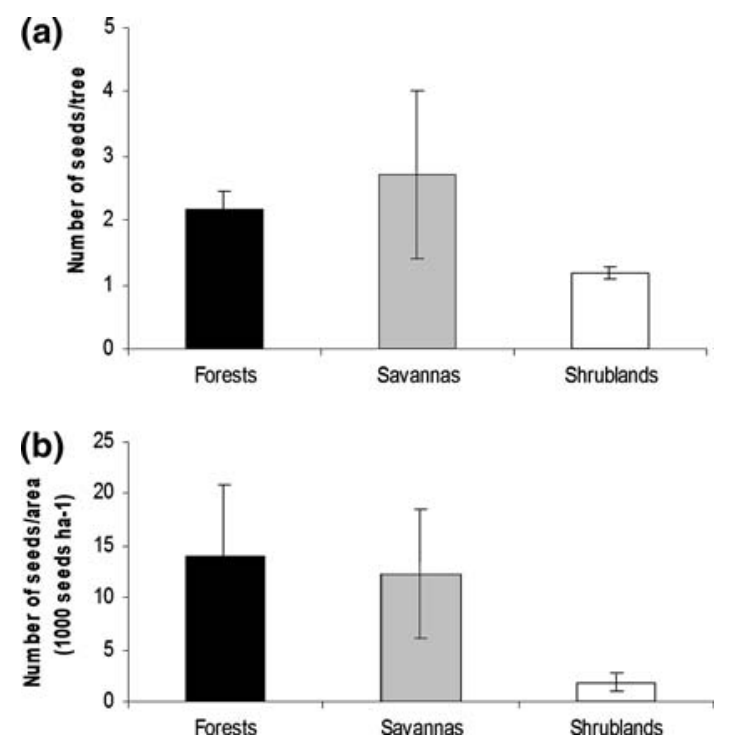

Figure 1. Seed production per tree $(\mathbf{A})$ and per area $(\mathbf{B})$ per vegetation type. Data are geometric means \pm 1 SE.

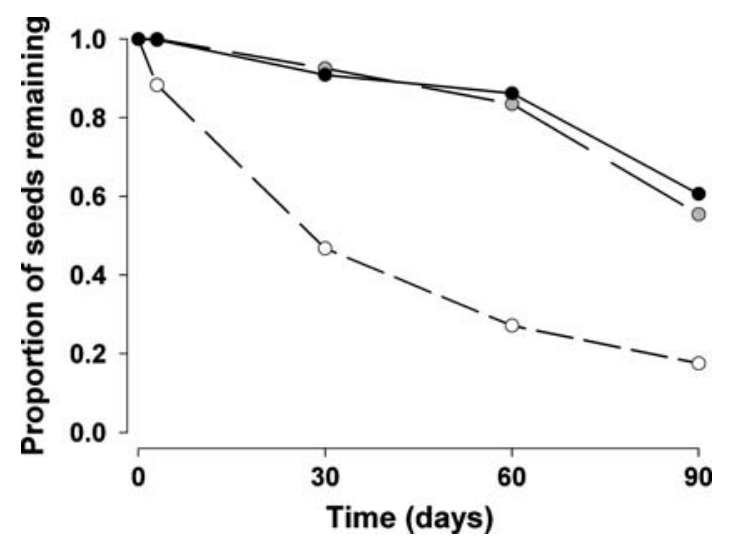

Figure 2. Seed removal per vegetation type. Proportion of seeds remaining over time in forests (black dots, solid line), savannas (grey dots, broken line), and shrublands (white dots, dashed line).

Among the retrieved acorns, the highest proportion was eaten in shrublands $(91 \%)$. Buried (that is, scatter-hoarded) acorns were more common in savannas $(33 \%)$ and forests $(24 \%)$ than in shrublands $(9 \%)$ (Figure 3). However, buried acorns only germinated in forests $(16 \%)$. Dispersal distances ranged from 0.7 to $23 \mathrm{~m}$ and in average were greatest in shrublands $(4 \mathrm{~m})$. Although most caches (that is, locations of buried acorns) contained a single acorn, we found three caches with more than one acorn at one of the forest sites. Evidence (footprints, dental marks on acorns, fur, burrows, and trapped individuals) indicated that
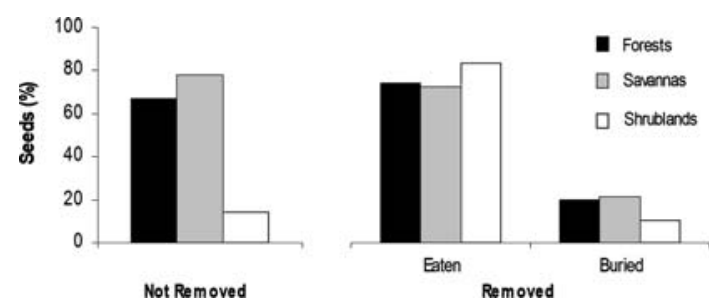

Figure 3. Seed fate per vegetation type (3 months after releasing). Eaten and buried seeds sum up to $100 \%$ of retrieved seeds; data are in percentages $\pm 1 \mathrm{SE}, n=1,510$.

the wood mouse (Apodemus sylvaticus) was the main agent responsible for acorn removal.

\section{Germination and Seedling Survival}

Shoots started emerging in February and continued until June; the median germination time was 4 months in all vegetation types. The proportion of seeds ultimately germinating (Kaplan Meier estimates \pm SE) was lower in shrublands $(56 \pm 3 \%)$ than in forests $(76 \pm 2 \%)$ and savannas $(84 \pm 2 \%)$ (Figure 4A), which agrees with hypothesis 3 (germination limitation). However, the difference among vegetation types was not statistically significant when accounting for dependence of germination rates within plots (Robust Cox regression: $\left.U_{2}=3.4, P=0.19\right)$. The ultimate proportion germinating was also not significantly different among vegetation types considering: all cohorts (ANOVA: $\left.F_{2,11}=2.41, P=0.14\right)$, cohort $1\left(F_{2,6}=1.4, P=\right.$ $0.32)$, and cohort $2\left(F_{2,2}=7.31, P=0.12\right)$.

Survival among the 575 emergent seedlings (Kaplan-Meier estimates) was much lower in shrublands $(18 \%)$ than in savannas $(60 \%)$ and forests $(69 \%)$ (Figure 4B). Seedling mortality was estimated to be three times higher in shrublands than in forests (Robust Cox regression: $z=2.4$, $P=0.015$ ) and savannas (Robust Cox regression: $z=2.4, P=0.017)$. The proportion of acorns that had died by the end of the survey was also significantly different among vegetation types (ANOVA: $\left.F_{2,7}=5.4, P=0.038\right)$ : more acorns died in shrublands than in the other two vegetation types $(P=0.05$, Tukey test $)$.

Within each vegetation type, there were no significant effects of shading categories (full-sun, halfshade, tree-shade, and shrub-shade) on seedling mortality (Robust Cox regression: $U_{3}=1.9$, $P=0.59$ for forests; $U_{3}=3.9, P=0.27$ for savannas; $U_{3}=1.5, P=0.69$ for shrublands). Among vegetation types, mortality was lowest among seedlings shaded by trees $(32 \pm 4 \%)$, higher among seedlings in full-sun $(47 \pm 4 \%)$ or in half-shade $(49 \pm 6 \%)$, 

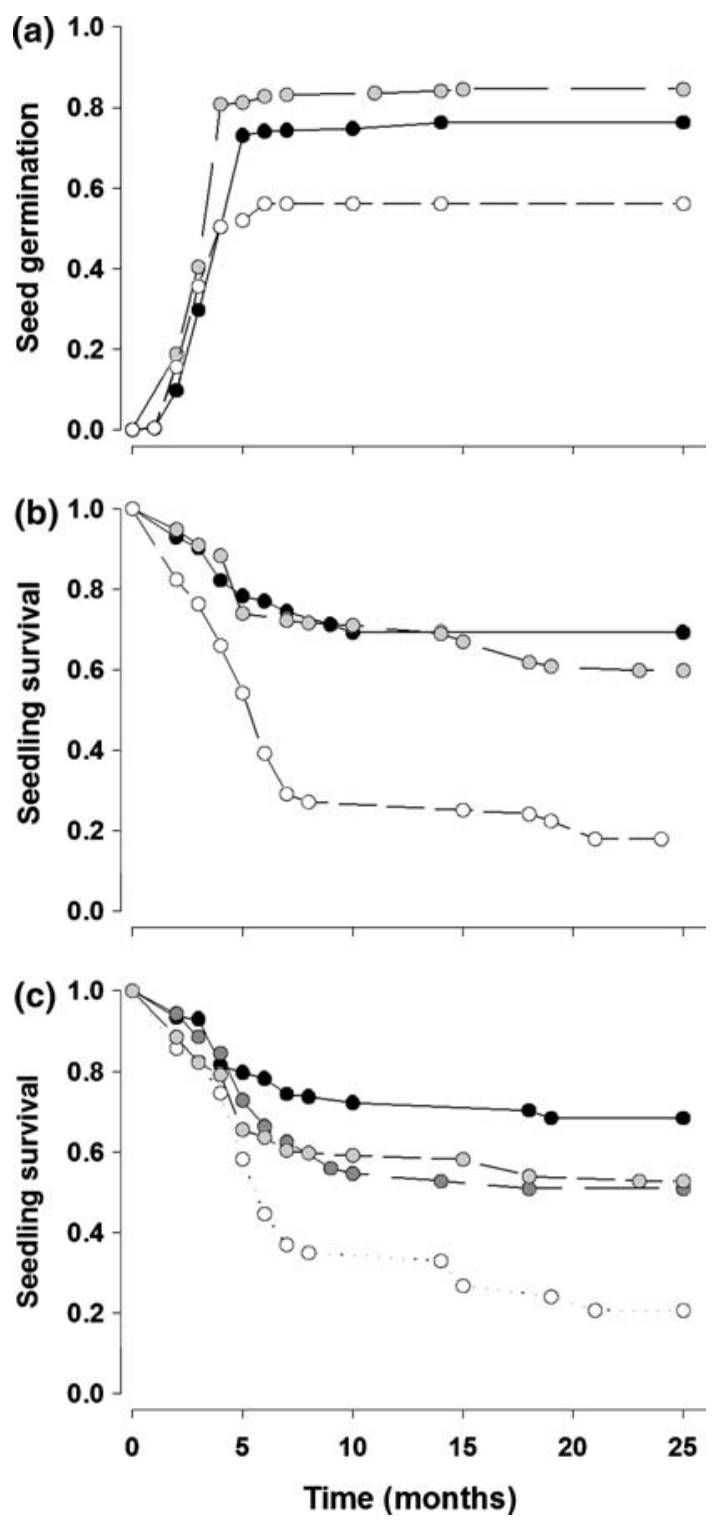

Figure 4. Performance of seeds (germination and survival) per vegetation type. A Proportion of seeds germinated (emergent seedlings); $\mathbf{B}$ and $\mathbf{C}$ proportion of seedlings surviving during the study period (KaplanMeier estimates). Lines in $\mathbf{A}$ and $\mathbf{B}$ represent forests (black dots, solid line), savannas (grey dots, broken line), and shrublands (white dots, dashed line). Lines in $\mathbf{C}$ represent seedlings shaded by trees (black dots, solid line), half-shaded by trees (dark-grey dots, broken line), in full-sun (lightgrey dots, broken line), and shaded by shrubs (white dots, dashed line).

and highest for seedlings shaded by shrubs $(79 \pm 6 \%)$ (Figure 4C). Among vegetation types, mortality below shrubs was significantly higher than mortality below trees (Robust Cox regression: $z=3.0, P=0.003$ ), whereas the difference in mortality with half-shade and full-sun was marginally significant. Overall, shading by shrubs and trees explained seedling mortality better $\left(R^{2}=0.10\right)$ than did vegetation type $\left(R^{2}=0.05\right)$. The main $(97 \%)$ natural cause of death for the 214 experimental seedlings was drought (seedlings were dried without being eaten); other causes were (in decreasing frequency) shrub-clearing practices and fire.

\section{Recruitment Cycle}

Overall, all four forms of recruitment limitation were more severe in shrublands than in forests and savannas (Figure 5). The strength of all types of recruitment limitation was similar between forests and savannas. Higher seed rain in forests compared to savannas was offset by higher pre-dispersal seed predation in forests; therefore source limitation was similar between these two vegetation types. In total, $33 \%$ of the seed rain was depredated in savannas and $37 \%$ in forests. In shrublands, seedsource scarcity and establishment failure seemed to be the strongest limitations for tree recruitment, whereas germination failure seemed to be less important and approached the values of savannas and forests.

As a consequence, the densities of established seedlings were similar between forests and savannas (although higher in forests) but very low in shrublands. Our estimate of seedling density is lower than the quantified natural regeneration, probably because natural regeneration included not only seed-originated seedlings, but also root sprouts (root sprouting is common among evergreen oaks).

\section{Discussion}

\section{Shrublands as an Arrested Successional Stage}

Vegetation changes in semiarid Mediterranean ecosystems worldwide have proved to be remarkably persistent (Fuentes and others 1984; Westoby and others 1989; Puigdefábregas and Mendizabal 1998; Holmgren 2002). Several studies indicate that replacement of original oak forests by Cistus shrublands remains in a condition of arrested succession for at least several decades (Natividade 1950; RivasMartínez and others 1990; Gonçalves 1991; Montero and others 1994). We have demonstrated that shrubland persistence results from multiple constraints on early oak life history phases including limitations on seed availability (that is, low seed production and high rates of infestation by weevils), dispersal (that is, lower rates of scatter-hoarding), germination (that is, high rates of post-dispersal 


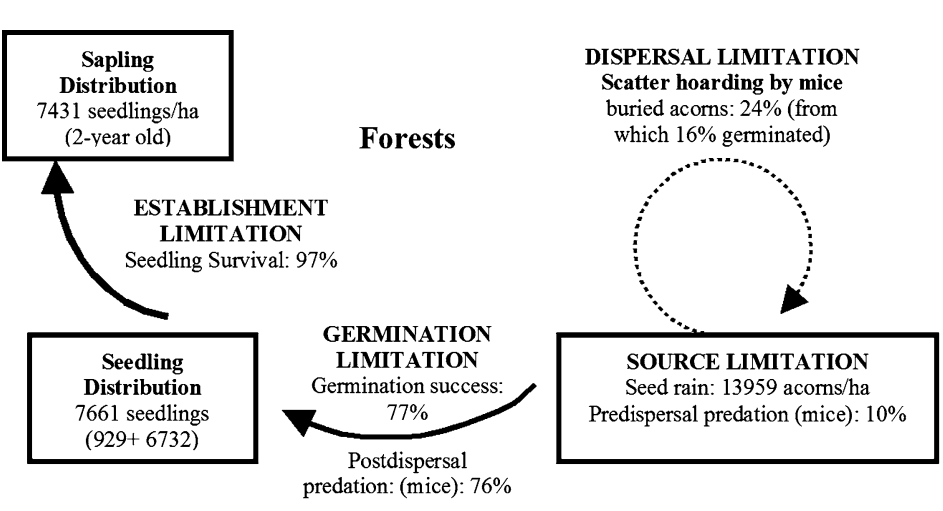

Figure 5. Estimated rate for some phases within the tree recruitment cycle. Final number of established seedlings/ha for each vegetation type, based on observed seed rain, mice predation and scatter hoarding, and rates of seed germination and seedling survival. Germination rates include both cohorts; survival rates include the 2003-cohort (2-year old seedlings); arrow and box thickness is proportional to the probability of seeds/ seedlings shifting to the next phase.
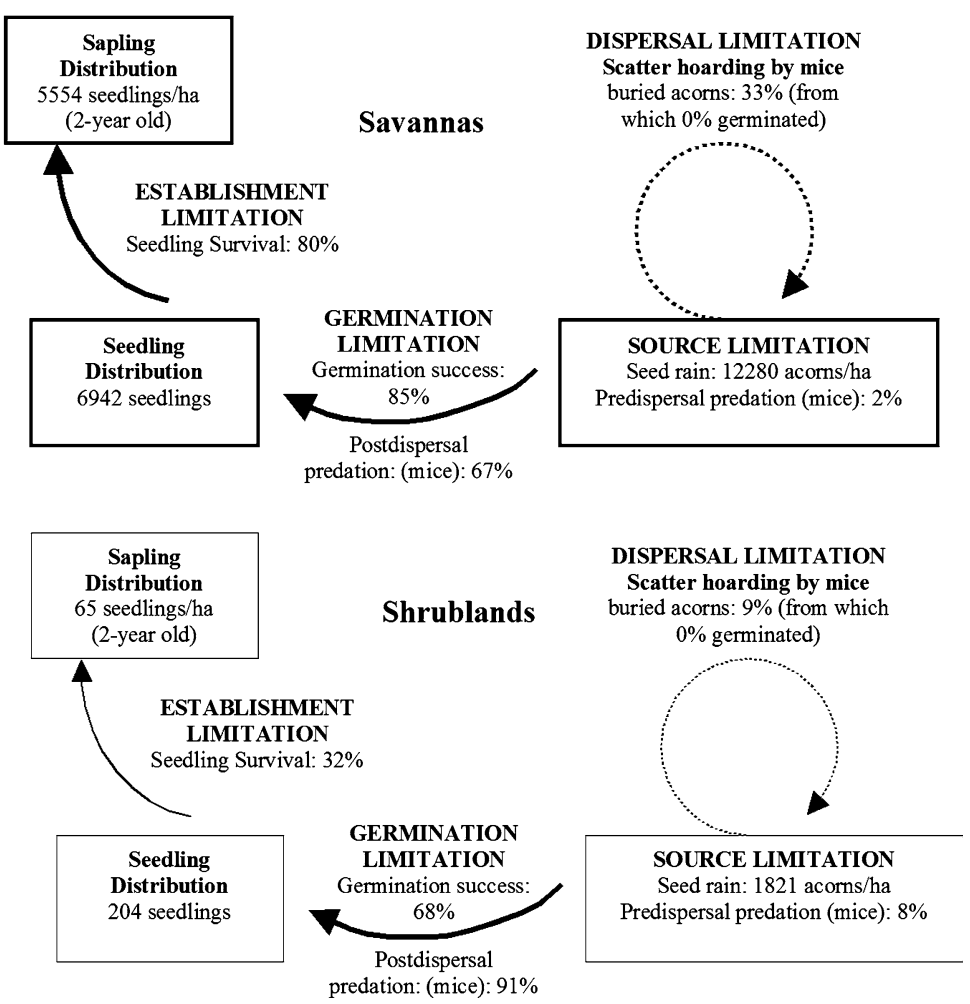

seed predation and low rates of germination), and establishment (that is, high seedling mortality).

We found that seed sources were scarce supporting our first hypothesis of higher source limitation in shrubland patches. From the few acorns that were available for dispersal, almost half suffered weevil-attack. Insect attack is at the cost of seed viability and seedling growth (Branco and others 2002). Seed removal (that is, potential dispersal) rates were about four times higher in shrublands than in savannas and forests, probably because mice populations are higher in shrubland patches (Pausas and others 2004; Torre and Díaz 2004) and because there is less food available. Comparable results have been found in other Mediterranean oak forests (Pons and Pausas 2007).
However, most of the seeds removed in shrublands were eaten rather than dispersed. The proportion that was scatter-hoarded was lowest in shrublands. Thus, our hypotheses 2 (dispersal limitation) and 3 (germination limitation) were supported. Furthermore, seed dispersal in shrublands is likely to be distance-restricted (sensu Schupp and others 2002) because the main agent responsible for long-distance dispersal-the European jay (Garrulus glandarius)-tends to avoid closed shrublands (Bossema 1979; Herrera 1995; Gómez 2003; Den Ouden and others 2005).

None of the acorns that mice cached in shrublands germinated. On the other hand, our experimental results indicate that if acorns are buried deep enough, germination in shrublands is comparable 
to that in oak savannas and forests. This discrepancy in germination success between the naturally buried acorns and our experimental ones may be explained by soil depth. In our experiments, seeds were fully buried (about $3 \mathrm{~cm}$ deep), whereas mice are probably not able to bury acorns that deep on the hard-rock schist soils of the study area.

Oak seedlings faced markedly higher mortality in shrublands than did seedlings in savannas and forests. Mortality was especially high under Cistus shrubs, higher even than under full-sun conditions. In summary, this means that the seeds that are produced and effectively dispersed in shrubland patches are not only fewer but also have lower probabilities of producing new recruits from which tree cover might increase. Also, in Spain seedling survival rates under Cistus shrubs are much lower than under other shrub species (Gómez-Aparicio and others 2004; Pulido and Díaz 2005) suggesting that in contrast to the facilitative effect of nurse shrubs on seedlings in forests and savannas, competition with seedlings seems to prevail in Cistus shrublands. Moreover, Cistus shrubs seem to have potential allelopathic effects able to inhibit seedling germination and growth (Chaves and others 2001; Lobón and others 2002).

\section{Tree Recruitment in Forests and Savannas}

Our results show that the four potential mechanisms of recruitment limitation, (namely seed availability, seed dispersal, seed survival and germination, and seedling survival) are comparable between forests and savannas, and contribute to a rather similar final density of established seedlings after 2 years of experimental planting. Nevertheless, natural regeneration was about three times higher in forests than savannas, implying higher difficulties for tree recruitment in savannas. Therefore, there might be other mechanisms limiting tree recruitment in savannas. Other studies have pointed to seed dispersal as the key process limiting tree recruitment in savannas, due to the difficulty of dispersing acorns to shaded sites (Pulido and Díaz 2005 for Spain). Among the mice-buried acorns, none were able to germinate in savannas, whereas $16 \%$ of buried acorns germinated in forests. Our experiment clearly shows that seeds can germinate and establish into seedlings in savannas (at least when buried at $3 \mathrm{~cm}$ depth). Finally, it is likely that our 2-year-old experimental seedlings will face increasing mortality by drought in the more open savannas than under the forest canopy in the coming years. In fact, we found seedling survival to be significantly lower in full-sun conditions than under tree shade, suggesting that forests provide better establishment conditions than savannas. In summary, our results demonstrate that tree recruitment in savannas does not seem to be strongly limited and that savannas represent an unstable vegetation type that could shift to forests.

\section{Implications for Restoration}

Our results show that oak seedling recruitment is severely limited in shrublands, which may explain the persistence of Cistus shrubland patches. Succession in these patches appears arrested, and unable to progress towards savannas and forests. Cork oak recruitment is also rare in the shrublands of eastern Spain, despite shrubland patches being close to oak forests (Pons and Pausas 2006; Pausas and others 2006). We found that all four forms of cork oak recruitment limitation were significantly more severe in shrublands than in oak forests and savannas, hence that oak seedling recruitment in shrubland was impeded in multiple ways. These results have significant implications for the restoration and conservation of Mediterranean oak systems. Management actions would need to simultaneously relieve low seed availability, high rates of seed predation, low rates of seed germination and low rates of seedling survival found in shrublands as compared to other vegetation states. Some concrete actions could include a combination of Cistus removal, acorn addition, planting of nurse shrubs (for example, Genista) to facilitate oak seedling germination and survival (Gómez-Aparicio and others 2004; Padilla and Pugnaire 2006; Smit and others 2007), as well as facilitating predators of rodents. Note that, also competition after tree establishment can additionally affect the ability of oaks to maintain a viable population in shrublands.

\section{Cork Oak Forest Regeneration under Climate Change}

Previous studies have indicated that the interaction between disturbance and overall climatic conditions is the key to understanding arrested successions (Holmgren and Scheffer 2001). In our system we found that multiple mechanisms inhibit cork oak recruitment at shrubland patches. It is likely that such mechanisms become reinforced by drier climate conditions especially on the already most degraded and xeric sites. Climate change models predict an increasing frequency of extreme drought and fire events for Mediterranean climate-regions (Cubash and others 1996; McCarthy and others 2001). Since 1972 mean annual temperature has 
clearly increased in the study region (Water Institute, National Meteorological Institute and Regional Coordination Commission of Algarve), a trend also observed in the rest of the country with the six hottest recorded years occurring in the last 12 years (for the period 1931-2000) (Cabrinha and Santo 2000; Miranda and others 2002). Because mean annual rainfall has not significantly changed in the study region, this increase in temperature implies higher evapotranspiration and plant water stress. Drier conditions will impose stronger constraints to seedling germination and survival especially on the drier southern exposures and open sites, but can potentially reduce seed production as well. Under the current and forecasted climatic trends, shrublands are likely to expand because Cistus shrubs are physiologically well adapted to dry conditions and recurrent fires (Werner and others 1998). More extensive shrublands will not only have lower oak seed availability, but also higher densities of mice predating on the oak seeds. All these conditions may further limit oak recruitment and favor the persistence of Cistus shrublands making conservation and restoration of diverse Mediterranean forests increasingly challenging.

\section{ACKNOWLEDGMENTS}

We thank the Associação dos Produtores Florestais da Serra do Caldeirão (Forest Producers Association) for helping in the selection of experimental sites; Eric Michel, Susana Acácio and Klara Humlova for helping during fieldwork; Francisco Rego and Frits Mohren for suggestions on the experimental design. This study was funded by the Portuguese Foundation for Science and Technology (Fundação para a Ciência e a Tecnologia fellowship SFRH/BD/5008/2001), and project Interreg IIIB Medoc RECOFORME. M. Holmgren also thanks the Dutch NWO Meervoud Programme (836.05.021). P.A. Jansen was supported by the Netherlands Organization for the Advancement of Tropical Research (NWO-WOTRO grant W85-239).

\section{REFERENCES}

Aschmann H. 1973. Man's impact on the several regions with Mediterranean climates. In: Di Castri F, Mooney HA, Eds. Mediterranean type ecosystems. Origin and structure. Berlin: Springer. pp 363-71.

Blanco E, Casado MA, Costa M, Escribano R, García M, Génova M, Gómez A, Gómez F, Moreno JC, Morla C, Regato P, Sáinz H. 1997. Los bosques ibéricos. Una interpretación geobotánica. Madrid: Planeta.

Borchert MI, Davis FW, Michaelsen J, Oyler LD. 1989. Interactions of factors affecting seedling recruitment of blue oak (Quercus douglasii) in California. Ecology 70:389-404.
Bossema I. 1979. Jays and oaks: an eco-ethological study of a symbiosis. Behaviour 70:1-117.

Branco M, Branco C, Merouani H, Almeida MH. 2002. Germination success, survival and seedling vigour of Quercus suber acorns in relation to insect damage. Forest Ecol Manage 166:159-64.

Cabrinha, V, Santo FE. 2000. Drought tendencies in mainland Portugal. In: Wilhite DA, Sivakumar MVK, Wood DA, Eds. Early warning systems for drought preparedness and drought management. Proceedings of an expert group meeting, Lisbon. pp 169-81.

Campos P, Díaz M, Pulido FJ. 1998. Las dehesas arboladas. Un equilibrio necesario entre explotación y conservación. Quercus 147:31-5.

Chaves N, Sosa T, Escudero JC. 2001. Plant growth inhibiting flavonoids in exudate of Cistus ladanifer and in associated soils. J Chem Ecol 27:623-31.

Conacher AJ, Sala M, Eds. 1998. Land degradation in Mediterranean environments of the world. Nature and extent, causes and solutions. Chichester: Wiley.

Cubash U, Von Storch H, Waskewitz J, Zorita E. 1996. Estimates of climate change in Southern Europe derived from dynamical climate model output. Clim Res 7:129-149.

Cox DR. 1972. Regression models and life tables. J Roy Stat Soc Ser B 34:187-220.

Den Ouden J, Jansen PA, Smit R. 2005. Jays, mice and oaks: predation and dispersal of Quercus robur and Q. petraea in North-western Europe. In: Forget PM, Lambert JE, Hulme PE, Vander Wall SB, Eds. Seed fate: predation, dispersal and seedling establishment. Wallingford: CAB International. pp 223-39.

Diniz AC. 1994. Os solos do montado e aptidão suberícola nos concelhos de Grândola, Santiago do Cacém e Sines. Correlações com a morte prematura do sobreiro. Silva Lusitana 2:247-67.

Friedel MH. 1991. Range condition assessment and the concept of thresholds: a viewpoint. J Range Manage 44:422-6.

Fuentes ER, Otaiza RD, Alliende MC, Hoffmann AJ, Poiani A. 1984. Shrub clumps of the Chilean matorral vegetation: structure and possible maintenance mechanisms. Oecologia 62:405-11.

Gómez JM. 2003. Spatial patterns in long-distance dispersal of Quercus ilex acorns by jays in a heterogeneous landscape. Ecography 26:573-84.

Gómez JM, García D, Zamora R. 2003. Impact of vertebrate acorn-and seedling-predators on a Mediterranean Quercus pyrenaica forest. For Ecol Manage 180:125-34.

Gómez-Aparicio L, Zamora R, Gómez JM, Hódar JA, Castro J, Baraza E. 2004. Applying plant facilitation to forest restoration: a meta-analysis of the use of shrubs as nurse plants. Ecol Appl 14:1128-38.

Gonçalves, JHC. 1991. Fitocenoses espontâneas dos sobreirais alentejanos: factores ambientais e dinâmica da vegetação associada a condições de mortalidade das árvores. Relatório Final do Curso de Eng. Silvicultor. Lisboa: Instituto Superior de Agronomia, Universidade Técnica de Lisboa. 133p.

Herrera J. 1995. Acorn predation and seedling production in a low-density population of cork oak (Quercus suber L.). For Ecol Manage 76:197-201.

Holmgren M. 2002. Exotic herbivores as drivers of plant invasion and switch to ecosystem alternative states. Biol Invasion 4:2533. 
Holmgren M, Scheffer M. 2001. El Niño as a window of opportunity for the restoration of degraded arid ecosystems. Ecosystems 4:151-9.

Klein JP, Moeschberger ML. 1997. Survival analysis: techniques for censored and truncated data. New York: Springer, p 502.

Latorre AVP. 1996. Restauración del alcornocal en Andalucía. Elección y manejo de especies Ecología 10:9-19.

Laycock WA. 1991. Stable states and thresholds of range condition on North American rangelands: a view point. J Range Manage 44:427-33.

Leiva MJ, Fernández-Alés R. 2003. Post-dispersive losses of acorns from Mediterranean savannah-like forests and shrublands. For Ecol Manage 176:265-71.

Li H, Zhang Z. 2003. Effect of rodents on acorn dispersal and survival of the Liaodong oak (Quercus liaotungensis Koidz.). For Ecol Manage 176:387-96.

Lobón NC, Gallego JC, Díaz TS, García JC. 2002. Allelopathic potential of Cistus ladanifer chemicals in response to variations of light and temperature. Chemoecology 12:139-45.

Mazzoleni S, Di Pasquale G, Mulligan M, Martino P, Rego F, Eds. 2004. Recent dynamics of the Mediterranean vegetation and landscape. Chichester: Wiley.

McCarthy JJ, Canziani OF, Leary NA, Dokken DJ, White KS, Eds. 2001. Climate change 2001: impacts, adaptation and vulnerability. Cambridge: Cambridge University Press.

Miranda P, Coelho FES, Tomé AR, Valente MA. 2002. 20th century Portuguese climate and climate scenarios. In: Santos FD, Forbes K, Moita R, Eds. Climate change in Portugal. Scenarios, impacts and adaptation measures - SIAM Project. Lisboa: Gradiva. pp 23-83.

Montero G, Torres E, Cañellas I. 1994. Regeneración de alcornocales. Síntesis bibliográfica Ecología 8:271-83.

Montero G, San Miguel A, Cañellas I. 2000. Systems of Mediterranean Silviculture: La Dehesa. Madrid: Grafistaff. S.L, p 48.

Myers N, Mittermeier RA, Mittermeier CG, Da Fonseca GAB, Kent J. 2000. Biodiversity hotspots for conservation priorities. Nature 403:853-8.

Nathan R, Muller-Landau HC. 2000. Spatial patterns of seed dispersal, their determinants and consequences for recruitment. Trend Ecol Evol 15:278-85.

Natividade, JV. 1950. Subericultura. Lisboa: Ministério da Agricultura, Pescas e Alimentação, Direcção-Geral das Florestas.p 387.

Olson DM, Dinerstein E. 2002. The global 200: priority ecoregions for global conservation. Ann Mo Bot Gard 89:199-224.

Padilla FM, Pugnaire FI. 2006. The role of nurse plants in the restoration of degraded environments. Front Ecol Environ 4:196-202.

Pausas JG, Pons J, Vallejo R. 2004. Cork oak restoration: developing techniques to enhance establishment of a threatened ecosystem (Spain). Ecol Restor 22:289-90.

Pausas JG, Ribeiro E, Dias SG, Pons J, Beseler C. 2006. Regeneration of a marginal Cork oak (Quercus suber) forest in the eastern Iberian Peninsula. J Veg Sci 17:729-38.

Pignatti S. 1978. Evolutionary trends in Mediterranean flora and vegetation. Vegetatio 37:175-85.

Pons J, Pausas JG. 2006. Oak regeneration in heterogeneous landscapes: the case of fragmented Quercus suber forests in the eastern Iberian Peninsula. For Ecol Manage 231:196-204.

Pons J, Pausas JG. 2007. Rodent acorn selection in a Mediterranean oak landscape. Ecol Res 22:535-541.
Puigdefábregas J, Mendizabal T. 1998. Perspectives on desertification: western Mediterranean. J Arid Environ 39:209-224.

Pulido, FJ. 1999. Herbivorismo y regeneración de la encina (Quercus ilex) en bosques y dehesas. Ph.D. Thesis. Cáceres: Universidad de Extremadura. p 146.

Pulido FJ, Díaz M. 2002. Dinámica de la regeneración natural del arbolado de encina y alcornoque. In: Pulido F, Campos P, Montero G, Eds. La gestión forestal de las dehesas. Mérida: IPROCOR. pp 39-62.

Pulido FJ, Díaz M. 2005. Regeneration of a Mediterranean oak: a whole-cycle approach. écoscience 12:92-102.

Putz FE, Canham CD. 1992. Mechanisms of arrested succession in shrublands: root and shoot competition between shrubs and tree seedlings. For Ecol Manage 49:267-75.

R Development Core Team. 2006. R: a language and environment for statistical computing. R Foundation for Statistical Computing, Vienna, Austria. http://www.R-project.org.

Retana J, Espelta JM, Gracia M, Riba M. 1999. Seedling recruitment. In: Rodá F, Retana J, Gracia CA, Bellot J, Eds. Ecology of Mediterranean evergreen oak forests. Berlin: Springer. pp 89-103.

Rivas-Martínez S, Lousa M, Díaz TE, Fernández-González F, Costa JC. 1990. La vegetación del sur de Portugal (Sado, Alentejo y Algarve). Itinera Geobotanica 3:5-126.

Sarmiento FO. 1997. Arrested succession in pastures hinders regeneration of Tropandean forests and shreds mountain landscapes. Environ Conserv 24:14-23.

Scheffer M, Carpenter S, Foley JA, Folke C, Walker B. 2001. Catastrophic shifts in ecosystems. Nature 413:591-6.

Schupp EW, Milleron T, Russo SE. 2002. Dissemination limitation and the origin and maintenance of species-rich tropical forests. In: Levey DJ, Silva WR, Galetti M, Eds. Seed dispersal and frugivory: ecology, evolution and conservation. Wallingford: $\mathrm{CAB}$ International. pp 19-33.

Seng M, Deil U. 1999. Forest vegetation types in the Serra de Monchique (Portugal): anthropogenic changes of oak forests. Silva Lusitana 7:71-92.

Smit C, Den Ouden J, Díaz M. 2007. Facilitation of holm oak recruitment by shrubs in Mediterranean open woodlands. J Veg Sci (still in press).

Torre I, Díaz M. 2004. Small mammal abundance in Mediterranean post-fire habitats: a role for predators?. Acta Oecologica 25:137-42.

Trabaud L. 1981. Man and fire: impacts on Mediterranean vegetation. In: Di Castri F, Goodall DW, Eds. Ecosystems of the world 11. Mediterranean-type shrublands. Amsterdam: Elsevier. pp 479-521.

Walter H. 1973. Vegetation of the Earth in relation to climate and the eco-physiological conditions. New York: Springer, $p$ 237.

Wang BC, Smith T. 2002. Closing the seed dispersal loop. Trend Ecol Evol 8:379-85.

Werner C, Correia OA, Ryel RJ, Beyschlag W. 1998. Modeling wholeplant primary production of macchia species: assessing the effects of photoinhibition and foliage orientation. Revista de Biologia 16:247-57.

Westoby M, Walker B, Noy-Meir I. 1989. Opportunistic management for rangelands not at equilibrium. J Range Manage 42:266-74.

Xiao Z, Jansen PA, Zhang Z. 2006. Using seed-tagging methods for assessing post-dispersal seed fate in rodent-dispersed trees. For Ecol Manage 223:18-23. 